\title{
PHASED MULTI-TARGET AREAL DEVELOPMENT COMPETITIONS: ALGORITHMS FOR COMPETITOR ALLOCATION
}

\author{
Pertti LAHDENPERÄ \\ VTT Technical Research Centre of Finland, \\ P.O.Box 1300, FIN-33101 Tampere, Finland \\ E-mail: pertti.lahdenpera@vtt.fi; Tel. +358-20 722 3440; Fax. +358-20 7223497
}

Received 31 March 2008; accepted 25 November 2008

\begin{abstract}
The prevailing practice in new areal real estate development is for public and private actors to perform their duties by turns. Yet, the planning process could benefit from simultaneous contributions from society and developers and their designers. That, again, requires that the municipality selects the private partner consortia prior to completion of the local detailed plan through a competition in order to find the most potential actors and the best ideas for implementation of an urban structure of high quality. Candidates will be attracted by offering them the right to implement a residential/business block as a developer. The several blocks involved in an areal development project, and the laboriousness of producing competitive solutions, require a well planned selection process. A novel multi-target competition process was developed which is presented in this paper with special emphasis on the allocation algorithms that allow selecting the most qualified competitors for parallel follow-up competitions from among a large group of registered candidates. The approach was tested in an actual real estate development project in the municipal district of Vuores which was the original reason for launching the study.
\end{abstract}

KEYWORDS: Urban planning; Real estate development; Competitive selection; Multi-target competition; Public-private partnership

\section{INTRODUCTION}

This study is based on the idea that the urban planning process can be developed in cooperation between society and developers and their designers also in the case of publicly owned areas. That requires selecting private actors for real estate development, who cooperate with the municipality on a detailed plan solution for the area, and on its completion implement the construction as a developer at own risk instead of the municipality drawing the plan alone or with a consultant. The rec- ognition of this possibility by the City of Tampere and its intention to make use of it in the development of the Vuores district led to this study which aims to develop practical tools and procedures in support of partner selection.

As will be substantiated later, such developer selection emphasises quality and competition where an implementer is chosen simultaneously for each block in a group of adjoining residential/business blocks. The described overall procedure is here referred to as multitarget competition (see Figure 1). 


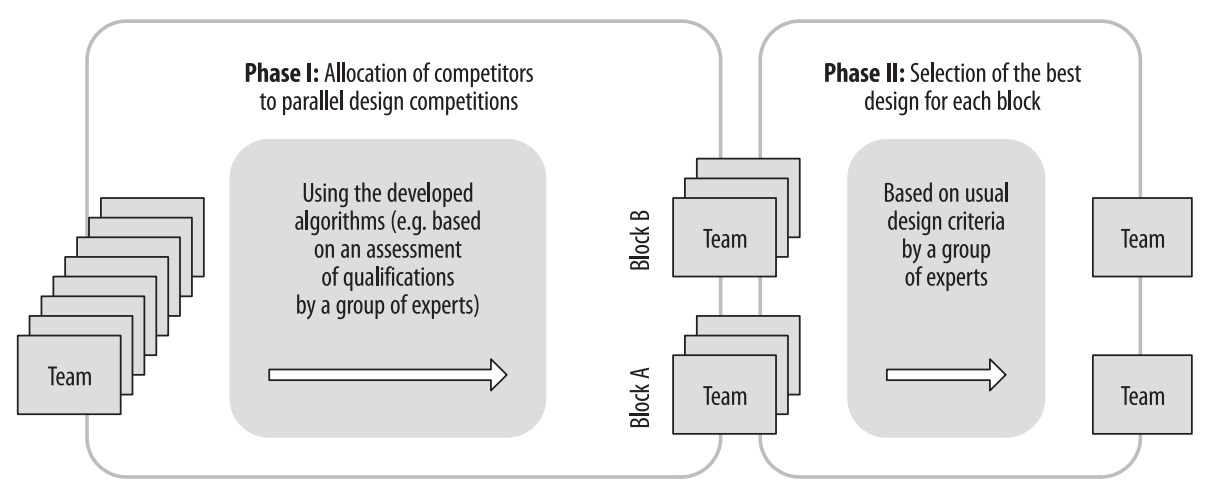

Figure 1. The basic idea of multi-target competition

Initially, all developer teams (consortia), based on their general competence, compete against each other for actual slots in the parallel competitions for blocks, unaware of which parallel competition their ranking order in the competition based on qualifications will lead to, if any. That depends on the consortia's and decision maker's valuations; the allocation of competition slots is case-specific and governed by many boundary conditions. In the second phase, the aim is to then select the team that comes up with the best proposal in each parallel competition as the implementer. Building rights serve as a competitive incentive, and participation in competition is a means for developers to acquire building land.

The entire two-phase competitive process is presented as a necessary framework, but the actual contribution of the work consists of multi-target competition selection methods that allow choosing competitors for parallel follow-up competitions from among a large group of candidate consortia in the initial phase. Two methods, or algorithms, were generated to meet the decision makers' (competition organisers') alternate strategies. Finally, experiences from the use of the approach in an actual areal real estate development in the Vuores area are presented. The overall process and the selection algorithms were both developed entirely as part of the study.

\section{CHALLENGES AND MEANS OF DEVELOPMENT}

\subsection{Aim of cooperation}

The prevailing planning and construction practice in many countries is for municipalities to carry out the city planning and hearing process without involving the developers - the latter are brought in only after the detailed plan is ready (Kurunmäki, 2005). This is only natural since, for instance, Finnish law prescribes community planning as the sole right of municipalities while demanding that the plan must provide preconditions for a good quality living environment (Maankäyttö, 1999).

Sequential areal planning processes of this type have, however, been criticised for slowness and inflexibility, especially in the case of growth centres, where land for residential construction has been in short supply. Plots have become available for construction at a slow rate, and the process has reacted slowly to changes in demand. At the same time, construction has been controlled quite tightly which may decrease developers' interest in the development of some areas (Taylor, 1998).

Väyrynen (2007) has recently redefined the problem of the traditional sequential process by suggesting that the formal detailed plan constitutes a sort of point of discontinuity in real estate development, especially from the 
viewpoint of knowledge utilisation. Only formal information transfers when the planning and implementation-phase actors are different parties that perform their work at different times in the traditional process. Also, the innovative ideas and market knowledge of the parties implementing the construction cannot be utilised by the planner.

Development of planning cooperation between municipalities and developers is suggested as a solution for more effective community and detailed planning. In Finland cooperation may be based on development of privately owned land according to land-use agreements or inclusion of partners in the planning process based on land acquisition by municipalities. The latter model makes use of private expertise while enabling more economic implementation combined with effective societal control. Therefore, it is also considered most likely to produce the best result of any of the alternative models - including the traditional one (Eerolainen, 2005).

The procedure based on cooperation can also be partly justified by practical experiences. Rowley (1998) reported about research focusing on private sector development projects which indicated that especially close cooperation between the public and private sectors is common to successful projects. Resources must also be invested in initial phase planning. The criterion is good urban planning which areal developers also regard as being in their interest. Kreukels and Spit (1990) also emphasise the benefits of the cooperation model that integrates different kinds of expertise.

\subsection{Utilisation of competition}

The cooperation model does, however, set new requirements for the selection of developers/implementers. In the traditional model, the plan sets sufficiently accurate boundary conditions for areal development together with building regulations, which means that imple- mentation of construction can in principle be entrusted to any competent actor. Meeting of statutory obligations suffices, and selections can be based on criteria other than those that guide areal development.

The situation is essentially different when the aim is to develop the process by overlapping detailed planning and construction design. Then, the implementers are in fact selected to develop the detailed plan proposal at a time when societal control mechanisms for the future construction are still undeveloped. This requires selecting partners whose input most likely leads to an excellent areal development result. The developer consortia are expected to contribute added value to the urban planning process.

Many potential actors operate in a functioning market which means that the best partners can be found through competition. Developers compete on the basis of various demonstrations, ideas and plans, but the decision making authority remains with the municipal organisation. Excellent solutions, later to be made part of the detailed plan, are developed on the basis of the best proposals. Thereby the views of various parties and market demand are taken into account, while also providing preconditions for quick construction.

The procedure based on design competition has proved superior in developing innovative solutions compared to engaging a single actor as designer straight away (Alexander and Witzling, 1990; Fisher et al., 2007). It allows charting a broad range of possibilities during the competition while also making a large number of alternative competition processes available for meeting different challenges (Alexander and Witzling, 1990; Eley, 1990).

Stenberg and Kadefors (2000) reported on Swedish competition-based implementer selection before the plan is finalised. The competition required planning, for which unconventional goals were set. The chosen actor was to develop an area at own risk - thus the 
competition was for plots, not procurement. Their conclusion was that competition led to good solutions that would not have surfaced without competition. Design competition has been applied to conveyance of plots (in addition to procurement) also in Finland, but only in areas covered by a completed town plan (e.g. Kauppinen, 2001) and primarily in the case of single blocks.

\subsection{The challenge of parallel competition}

When plans are drawn for areas, significant new building rights are created which means that, in order to maintain competition in the market, it is often sensible to select several implementers for the entire area - such as a different consortium for each residential/business block. Competition for a group of blocks involves enough volume to spark the interest of construction sector actors. Simultaneous competition is naturally a logical consequence of the objective of coordinating adjacent blockspecific solutions for the benefit of coherent urban design.

The combined parallel competition model presents an additional challenge to the organising of competitions and is a factor that differentiates the process at hand from the known competition processes referred to. Some blocks may be more attractive than others, and there is the risk that consortia are interested in the same ones. On the other hand, the number of competitors may become so large that many actors prepare their plans in vain. That is detrimental to the competition process over the long term.

Thus, a key question is how to secure the actors' interest toward each block so that the expected value of winning from the viewpoint of consortia is sufficient for them to get seriously involved in the competition and that it results in the best possible outcome from society's viewpoint? This may often require phas- ing of competition and allocation of consortia to parallel competitions and, more generally, development of sufficiently uncomplicated, fair and transparent competition models.

\subsection{Approaches to development work}

The action-oriented and constructive paradigms are used as the primary research approaches. The aim of the action analytic approach is to create new and better systems by concentrating on a single or a few observed subjects (Mäkinen, 1980); in this case to develop a new general process. The focus of the case study were the planning/implementation processes concerning the new Vuores municipal district, initially especially the Mäyränmäki section.

The process was developed on the basis of existing knowledge (see Lahdenperä, 2007) as concerns procurement methods including design (e.g. Lahdenperä, 2001; Lahdenperä et al., 2005), prequalification procedures of construction (Lahdenperä and Sulankivi, 2001) and design competition practices (e.g. Alexander and Witzling, 1990; ATL et al., 2006; RIL, 2000; SAFA, 1994). Various possible alternative processes were generated and assessed in cooperation with sector actors. The development work itself is not dealt with here since the process is presented merely as a framework for competitor allocation and the required algorithms in multi-target competition.

No existing procedures for generating algorithms were found in the conducted literature survey which is why the development involved constructing innovative (rather than deductive) solutions for the problem at hand, and proving of the functioning of the approach in practice. Thus, the scientific approach was constructive (cf. Kasanen et al., 1991; Kasanen et al., 1993).

The constructive research approach refers to problem solving through the building of a model, a diagram, a plan, etc. where the desired end result guides the work instead of, for 
instance, arriving at a result through logical deduction from theoretical premises. Solutions were ideated on the basis of the competitive situation and the objectives of the competition organiser and participating consortia, and were further organised into algorithms. Scientific validity was confirmed by practical workability and indicated theoretical linkages.

The constructions developed as part of this work are thus allocation algorithms of multitarget competition. Generally, an algorithm is any particular procedure for solving a certain type of problem (Gramercy Books, 1994). In practice, algorithms often include repetitions and branches based on the conditions of logical reasoning that they incorporate. Yet, they also have to be finite.

The solution method based on algorithms was selected since the development of a high quality built environment requires disciplined decision making that promotes competition and offers incentives. This minimises the randomness and politicisation of decision making which would endanger the qualitative goals. Decision making based solely on intuitive reasoning runs numerous risks which weakens the results: the guiding influence of the objectives diminishes, group dynamics affect the result, and the lack of credibility dampens the consortia's enthusiasm to compete. Systematic, expert and transparent decision making, on the other hand, spurs competitors to a good performance in line with the objectives. Perceived fair decision making is a crucial factor from the viewpoint of actors when considering whether to participate or not (Stenberg and Kadefors, 2000).

In view of the nature of the research problem, the use of deterministic algorithms can also be questioned: a solution may not always be found. Consequently, flexibility must be built into algorithms to find the best possible solution; different parameters may have to be used to find that solution. Thus, a factor that initially seems to work at counter purposes to an approach, may actually be strongly sup- portive of algorithms: it is generally not possible for decision makers to generate multiple options, which are often required to find a solution in line with the incentive principle, during the meeting where a decision is made without the use of IT which, again, calls for systematically defined algorithms.

\subsection{Two-phase partner selection process}

A process was developed as a solution to the presented challenge where the best consortia having announced their candidacy are allocated to parallel block-specific design competitions for selecting planning partners. On the task level, the two-phase selection process is as follows (Figure 2):

1. Opening of competition. As the draft of the detailed plan is finished and the block layout has taken shape, the competition is publicly announced opened. The goals set for the planning of the target area, the progress and rules of the selection process, the demands on implementers, selection criteria and procedures of planning and conveyance of plot are recorded in the competition programme available to the candidates.

2. Preparation of account of qualifications. Companies organise into consortia with comprehensive expertise in areal planning and implementation. The consortia agree on the principles of planned cooperation and prepare participation applications whereby they prove their competence for implementing a target and that they have the financial and other resources set out in the competition programme.

3. Assessment of competence. The municipality ascertains the general competence of the consortia having submitted an application for participation in planning and implementation (for criteria see Table 1, part A). Here we are dealing with minimum requirements, definite factors that are either met or not (societal obligations, financial resources, minimum experience). 
4. Assessment of qualifications. The municipality together with its experts assesses the strengths of the consortia deemed competent in relation to preset criteria primarily on the basis of previous experience and demonstrated skills of the consortia and their staff (see Table 1, part B). In the assessment the different degrees of properties are identified so as to allow recognising the differences between the consortia.

5. Establishment of ranking order. Consortia are ranked solely on the basis of how they fared in the assessment of qualifications. Properties corresponding to all criteria are considered, and their assessed degrees are used to arrive at reference figures for different consortia which are used to rank them in each case. Criteria are generally weighted differently.

6. Allocation of competitors. Consortia for parallel design competitions are selected so that a finite number of competitors participate in each block-specific competition (e.g. 2-4 teams). The competitors are selected in ranking order on the basis of their stated priorities for implementing blocks.

7. Preparation of design proposal. Competing consortia prepare their proposals for the blocks assigned to them. The design proposal is a technical and functional description of the target's architecture (site plan, elevation and floor plan, etc.). Process-related is- sues may also be the subject of design in addition to the product.

8. Assessment of proposed solutions. An expert group set up by the municipality evaluates the proposed solutions submitted under a pseudonym as well as their compatibility with the set objectives in accordance with the weighted criteria of the competition programme (see Table 1, part C). The proposals are assessed comprehensively as to the relative compatibility of their subsections to allow placing them in ranking order.

9. Conditional selection. The consortium that did best in the design competition is selected as the partner to implement the block (or part thereof) in question. The assessment of qualifications is not considered here or it carries little weight. Sometimes development of the area as an entity may require deviating from the ranking order which means that the winner must be rewarded by other means.

10. Planning in partnership. The municipality and the selected consortia continue development of the plan and the blocks on the basis of proposals. The work combines the planner's conception with the implementers' market savvy and production knowhow while the design of parallel blocks is viewed as a whole. Earlier presented goals guide design and become increasingly specific along the way.

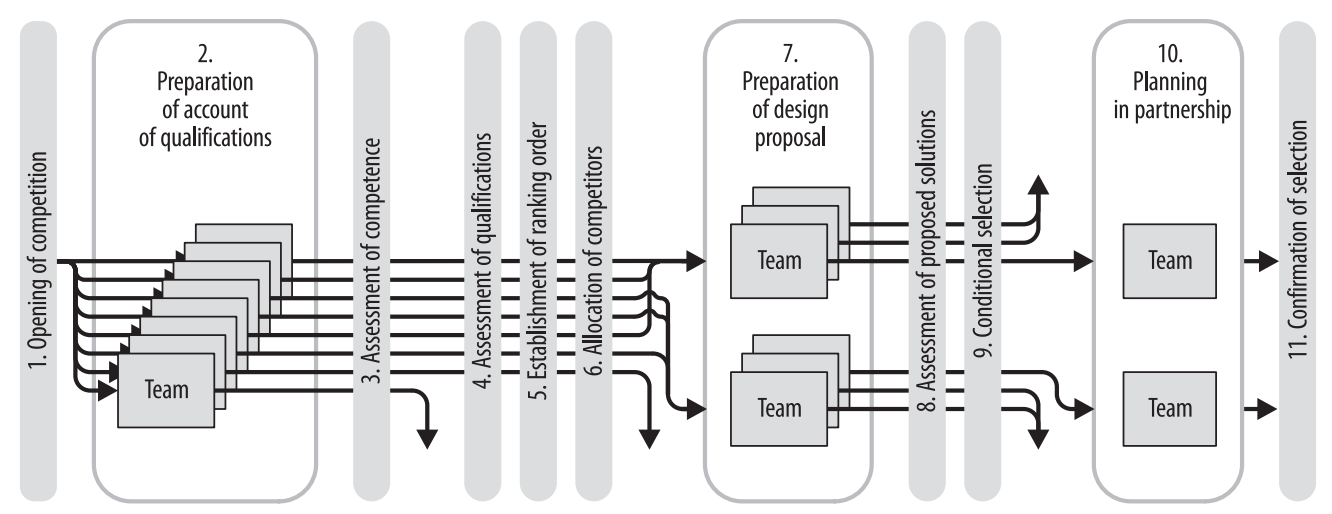

Figure 2. The tasks of the process for selecting planning partners 
Table 1. Example criteria for selection of planning and implementation partners

\section{A. Assessment of competence}

Legal obligations (Laki, 2006; Rakentamisen, 2007)

- is entered in 1) trade, 2) preliminary tax withholding, 3) employer, and 4) value-added tax payers' register

- has paid 5) taxes and 6) employee pension contributions (or has corresponding payment schemes)

- has informed about 7) collective bargaining agreement to be applied to the work or the key terms and conditions of employment

Capabilities and technical prerequisites (Rakentamisen, 2007)

- has the competence to operate in sector demonstrated by reference projects

Financial preconditions

- financial statements indicate that owners' equity is at least 50\% of share capital (Rakentamisen, 2007)

- turnover of earlier years is sufficient in relation to scope of target of competition

\section{B. Assessment of qualifications}

Design expertise (designer's evaluation)

- experience and references

- competition record and published projects

Implementation skills (developer's/implementer's evaluation)

- experience, references and client feedback from earlier projects

- production control and quality assurance

Consortium's internal cooperation (evaluation of integration of know-hows)

- previous cooperation between parties

- available methods and systems of cooperation

Consortium's resources (availability of expertise/capacity for project)

- key personnel assigned to project

- total available resources

C. Assessment of proposed solution (e.g. product-related criteria for residential blocks, Huovila, 2005)

Overall solution (integration of various partial solutions)

- uniqueness (innovativeness)

- architecture (high standard)

- public space (block-specific integrity, public and intra-block urban space)

- impact of construction on environment (natural elements)

Living

- innovativeness of solution (different dwelling sizes and types)

- modifiability of dwellings (auxiliary dwellings, connectability)

- versatility of spatial solutions (utility rooms; work, hobby and common spaces)

- views and light conditions (placement of buildings in terrain)

- outdoor living (pleasantness, sunniness, ground-level yards/dwelling-specific terraces)

Outdoor areas and yard arrangements

- yards, playgrounds, planted areas (as a whole, arrangement)

- hierarchy, safety and shelter provided by outdoor areas

- microclimate (e.g. sunniness and windiness)

- ecological treatment of storm waters (absorption, basins)

Traffic and parking arrangements

- parking, access to plots (parking spaces, bicycle shelters, pleasantness, townscape, controllability)

- light traffic routes (access, services, nature)

- traffic within blocks (safety, flow)

Buildings

- life-cycle principle (energy economy, modifiability, no risk)

- performance (maintainability)

- solutions that support sustainable development

- construction in phases 
11. Confirmation of selection. When the detailed plan produced in cooperation has been approved and is legally valid, the preconditions for confirming the plot division and subsequent conveyance of plots (sale or rental) to the partners involved in planning exist. The terms of conveyance are made to include a condition concerning as-designed construction while the detailed plan can be less restrictive than usual.

Allocation algorithms pertain to phase 6 of the process: how competitors are selected from among the ranked consortia for parallel design competitions.

\section{ALLOCATION PROCEDURES}

\subsection{Basic principles and input data}

Objectivity and transparency of decision making and equal treatment of candidates are general principles of selection development. Superiority established in assessment must also be rewarded according to the competition and incentive principle. That is, consortia are to be selected as competitors for the block design phase in ranking order.

Since we are dealing with a multi-target competition and do not know which targets (blocks) various candidate consortia vie for, each must be evaluated against all others. They can be placed in ranking order, for instance, on the basis of value tree-based criteria and weighted point scores (e.g. Clemen, 1996) or according to the methods of the analytical hierarchy process (e.g. Saaty, 2001). When the ranking order has been established, the points scored by consortia are of no significance unless the decision maker wishes, for instance, to limit the number of teams involved in different selection rounds on the basis of large point differences.

Along with competitiveness, the allocation of the consortia is also guided by, for instance, the chosen allocation strategy. The following options, explained in more detail later, are available:

- Selection based on consortia's priorities. The (block) priorities reported by a consortium indicate its order of preference for implementing the targets. The groups can in turn select, in accordance with pre-reported priorities, the competition they want to participate in based on their ranking order.

- Selection based on decision maker's priorities. The targets are placed in an order of importance based on the decision maker's (block) priorities which is also the order in which actors are selected for competitions. The best consortium having expressed its interest is selected for the target up for selection based on the order of importance.

Thus, it is clear that the priorities reported by consortia are also used as input data in selection, either as such or combined with priorities defined by the decision maker. Many other factors also guide practical allocation. The decision maker must, for instance, decide whether to use so-called matching allocation which will be presented later.

In the algorithm based on the decision maker's priorities, possible use of so-called round quota limitation prevents a consortium from being selected for more targets than the number of the selection round in progress. In addition to these general basic definitions, the decision maker is also to decide the other variable values presented at the top of Table 2 which also affect the shaping of the final allocation process.

The decision maker is to determine the lengths of rounds: the number of consortia participating in each round is essential in both algorithms. The possible round length based on the number of blocks applies only to selection based on the decision maker's priorities. Similarly, in selection based on consortia's priorities, it has to be decided whether a developer 
Table 2. Variables of allocation algorithms (related to Figures 3 and 4 below)

Variables whose values the user (decision maker) selects for implementing allocation

$\mathrm{c}_{\mathrm{d}}=$ max. no. of competition slots allowed a single team; limit set by selector

$c_{r}(r)=$ no. of competition slots allocated to a team in one round $r$

$\mathrm{T}$

$c_{t}(\mathrm{t})=$ max. no. of competition slots received by team $t$; limit set by team

$\mathrm{T} \quad \mathrm{D}$

$\mathrm{n}_{\mathrm{t}}(\mathrm{r})=$ no. of teams (consortia) included in allocation round $r$

$\mathrm{T} \quad \mathrm{D}$

$\mathrm{n}_{\mathrm{k}}(\mathrm{r})=$ no. of targets included in allocation round $r$

$\mathrm{w}=$ no. of competition slots to be filled at each target (block)

Variables describing consortia

$\mathrm{t} \quad=$ ordinal number of team (consortium) with first priority for allocation

$\mathrm{u}=$ ordinal number of team to be reallocated in matching allocation

T D

$\mathrm{v} \quad=$ ordinal number of team to be entered in slot freed due to matching allocation

Variables describing allocation priorities

$\mathrm{p}_{\mathrm{d}}=$ decision maker's (competition organiser's) block-specific priority

$\mathrm{D}$

$\mathrm{p}_{\mathrm{t}} \quad=$ team's (competing consortium's) block-specific priority

$\mathrm{T}$

$=$ priority of team up for selection in matching allocation

$\mathrm{T}$

$\mathrm{x}_{\mathrm{d}}=$ decision maker's priority number for target subject to matching

$\mathrm{D}$

$\mathrm{y}_{\mathrm{t}}=$ priority below highest unrealised priority (direct allocation)

$\mathrm{z}_{\mathrm{t}}=$ new priority of team to be reallocated in matching allocation

Variables describing targets (blocks) of allocation

$\mathrm{i} \quad=$ symbol of target with first priority in allocation

$\mathrm{j} \quad=$ symbol of target up for reallocation of team in matching allocation

$\mathrm{k}=$ symbol of target in direct allocation when seeking highest free priority $\mathrm{T}$

$1=$ symbol of target in direct allocation below highest free priority $\mathrm{T}$

$\mathrm{m}=$ possible substitute slot (target) in matching allocation $\mathrm{T}$

$\mathrm{o} \quad=$ target that may become free; to be immediately filled in matching allocation $\mathrm{T}$

Other auxiliary variables in allocation

$\mathrm{a}=$ the longest round length in terms of teams, i.e. $\max . \mathrm{n}_{\mathrm{t}}(\mathrm{r})$, when $\mathrm{n}_{\mathrm{t}}(\mathrm{n})<\mathrm{n}_{\mathrm{t}}(\mathrm{n}+1) \quad \mathrm{T}$

$\mathrm{b}=$ the longest round length in terms of targets, i.e. $\max . \mathrm{n}_{\mathrm{k}}(\mathrm{r})$, when $\mathrm{n}_{\mathrm{k}}(\mathrm{n})<\mathrm{n}_{\mathrm{k}}(\mathrm{n}+1) \quad \mathrm{T}$

$\mathrm{c}_{\mathrm{k}}(\mathrm{t})=$ max. no. of competition slots team $t$ may receive

$\mathrm{d}=$ no. of teams entered in competition in the round in question (for termination test) $\mathrm{T}$

$\mathrm{r} \quad=$ allocation round counter

$\mathrm{q}_{\mathrm{r}}=$ no. of competition slots allocated to team in the round in question

$\mathrm{q}(\mathrm{t})=$ total no. of competition slots allocated to team $t$

$\mathrm{s}(\#)=$ no. of teams entered in competition (\#)

T: allocation based on consortias' (teams') priorities (Figure 3)

D: allocation based on decision maker's priorities (Figure 4)

can be selected to compete for more than one target during a single selection round.

The maximum number of competition slots a consortium may have can be regulated by the decision maker as well as the consortium itself. The number of consortia included in competitions can also be set by the decision maker. In the prepared algorithms it is the same for all targets.

\subsection{Selection based on consortia's priorities}

In selection based on consortia's priorities (SCP), consortia may select in the established ranking order the competition they wish to participate in. The idea is that the selection process yields the best result when consortia are highly motivated, which is the case when they 
compete for the targets (blocks) they find most interesting. Felt interest may vary if targets deviate from each other as to production volumes, production technologies or market outlook. The allocation proceeds as follows (Figure 3):

- When registering for a competition, the consortia indicate which targets they wish to compete for. The targets are prioritised by assigning 1 to the target most desirable to the candidate, 2 to the second best one, etc. If a consortium does not register its interest in a certain target, it cannot be chosen to compete for it. On the other hand, non-registration would not improve its chances of being selected to compete for the registered targets unless the organiser of the competitions decides otherwise.

- Consortia are reviewed in ranking order in accordance with set restrictions (variable selections). Each consortium under examination is entered in the highest priority competition it has indicated interest in where slots are still available. In case a candidate has not indicated interest in competitions where slots are still open, the next best candidate is allowed an opportunity to enter by applying so-called direct allocation.

- At times so-called matching allocation may be required. Then, if the consortium up for selection cannot be allocated a slot directly based on any priority indicated by the consortium, even if open slots exist, an attempt is made to find a slot by reallocating some consortium from the competition slots for the blocks indicated as a priority by the group up for selection. Search is launched again starting from the highest unrealised priority of the consortium up for selection.

- In the search for a consortium to reallocate, only those that are already placed and lower in ranking order than the one up for selection are considered. The search is conducted in reverse en- try order, and an effort is made to find the most desired alternative slot for the lower ranked consortium so that the consortium up for selection can be placed in the freed slot. In case reallocation is not possible within the boundary conditions, the next consortium is allowed to select.

\subsection{Selection based on decision maker's priorities}

In selection based on the decision maker's priorities (SDP), the decision maker ranks the targets (blocks) in order of importance which is also used for selection. The best possible consortium is selected in turn for each target. The more important the successful implementation of the target from the decision maker's viewpoint, the better the consortia selected for the competition on average. The basis of importance may be the target's position in the townscape or how challenging the implementation is. The allocation proceeds as follows (Figure 4):

- When registering for the competition, consortia indicate the targets that they wish to compete for according to the yes/ no principle where the priorities for the consortia have no methodical significance. (Yet, there are good grounds for asking about priorities to allow applying the alternative allocation principle especially in unresolved situations.) If a consortium does not register its willingness for a target, it cannot be selected to compete for it either.

- The targets are examined in the decision maker's order of priority (importance) in accordance with set restrictions (variable selections). The best possible consortium in ranking order is always chosen for a competition. The consortium must be one whose (alternation-inducing) selection round-based quota and overall quota are not filled. This is the procedure followed in so-called direct allocation where a slot once earned cannot change. 


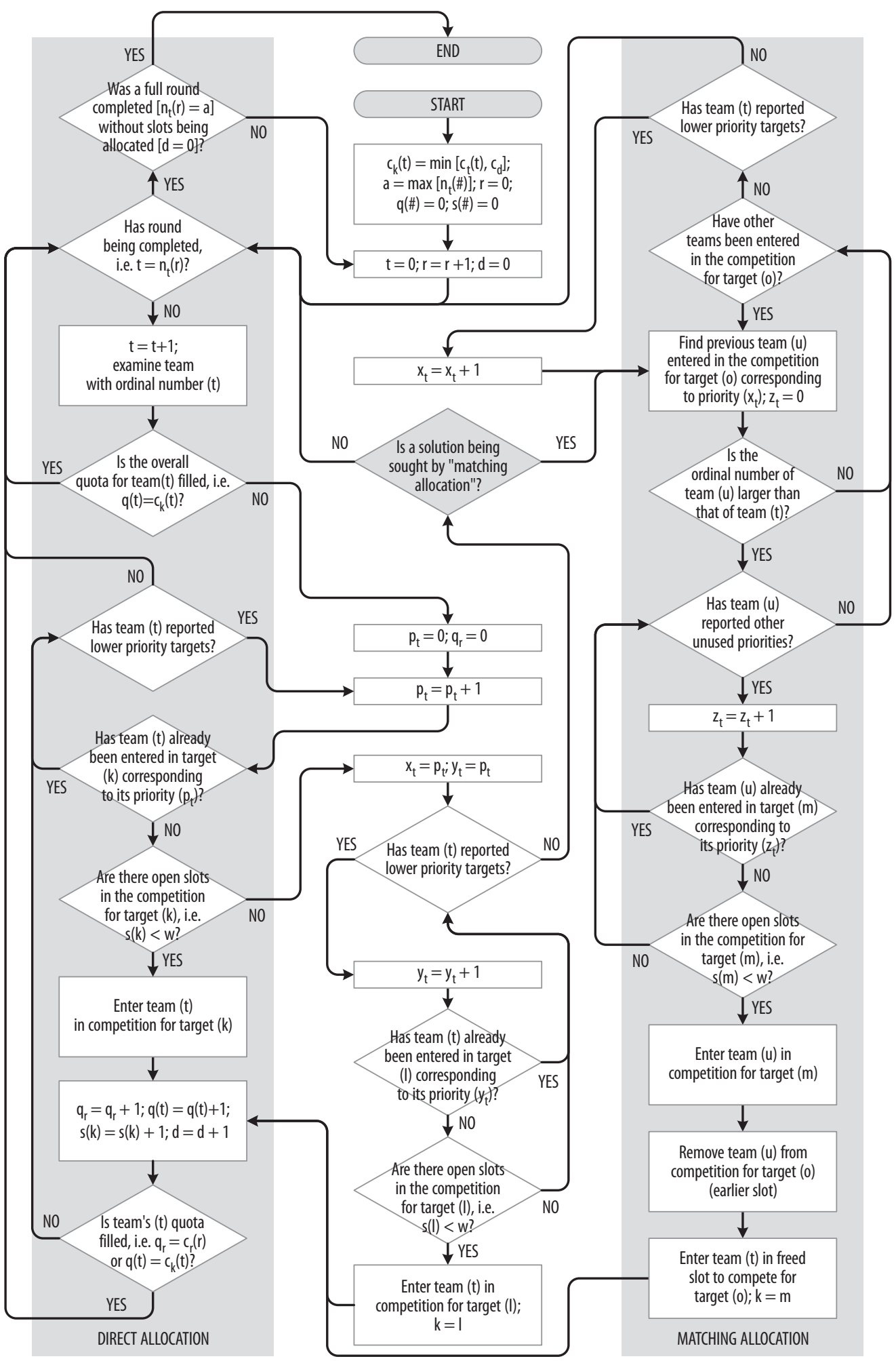

Figure 3. Allocation based on consortia's priorities (SCP) as a flow chart 


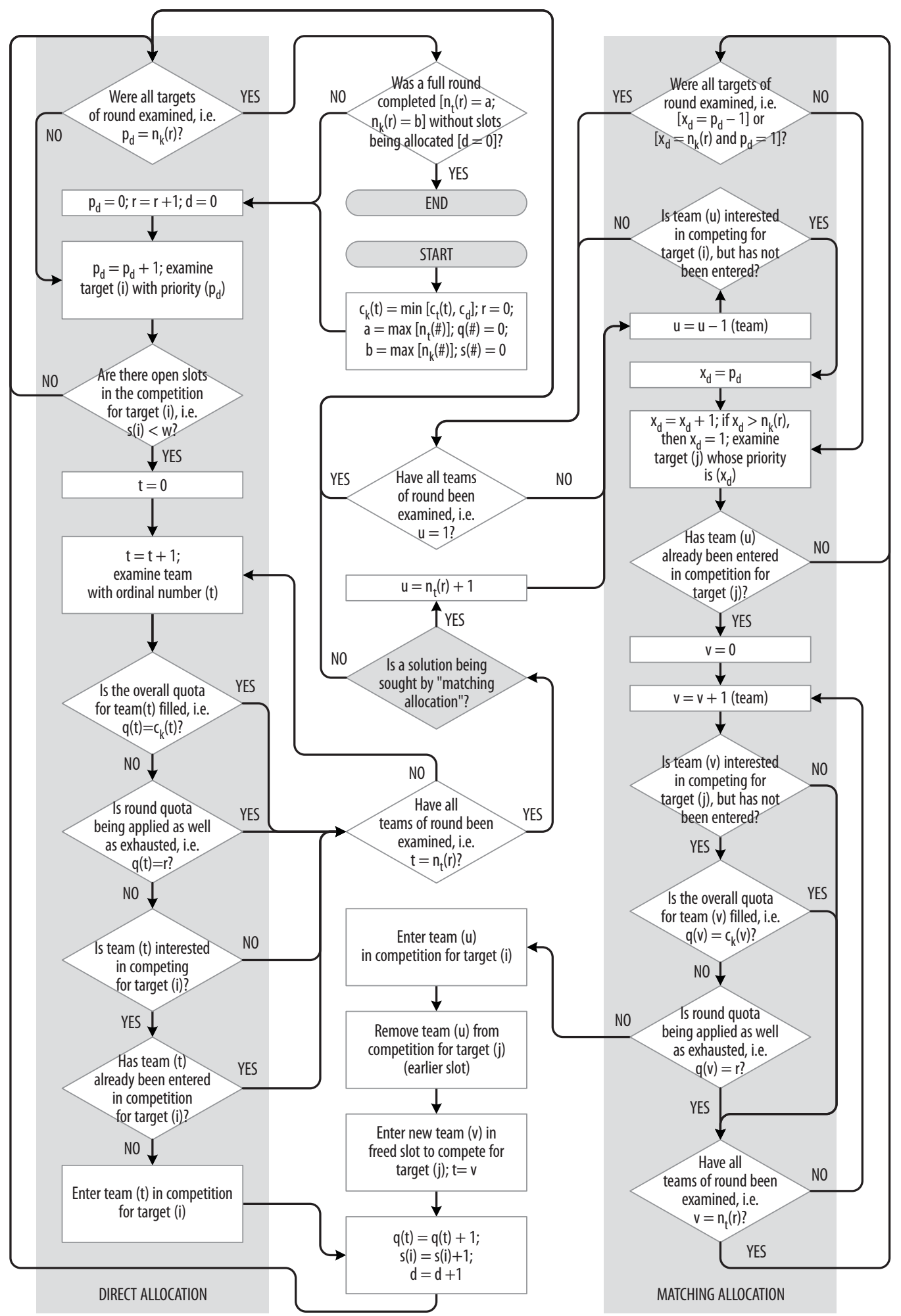

Figure 4. Allocation based on decision maker's priorities (SDP) as a flow chart 
- At times so-called matching allocation may be required. There, if a consortium is not found for a competition slot in a certain round, although all consortia included in the round are reviewed, the consortia already entered in various competitions are reviewed. Then a consortium is sought, starting with the one with the lowest ranking, that can be entered in the competition in question by pulling it out of another competition for which a substitute consortium can be found.

- The competition slot to be freed by the consortium intended for reallocation is sought starting with the target after the one up for selection in order of priority (by taking the step from the lowest target priority to the highest one). The aim is to always find the best possible substitute consortium with room in its quotas. If a substitute consortium is not found, reallocation is not made, but a search is launched for consortia for the competition for the next target in order of priority.

\subsection{Practical aspects of algorithms}

The allocation process becomes quite complicated due to case-specifically defined and regulated boundary conditions that define the actual order of selection. Yet, that is justified since a highly simplified procedure does not generally provide the most practical solution. The following seems to be true as regards variable selections:

- When the number of consortia included in (early) rounds is large, competitions involve relatively more consortia than in short rounds. This is justified when seeking competitors and attempting to maintain genuine competition.

- When the number of targets (or blocks) in early rounds is small in SDP, relatively better competitors are selected for the targets considered most important by the decision maker than if all targets are included in the initial rounds.

- An increase in the number of selections at a time in SCP enhances the situation of the top consortia since they can participate in competitions of higher priority to them even though the number of slots stays the same.

- The number of selections for a target in a single round is restricted to one in the SDP algorithm since it was not considered to be in line with the idea of multitarget competition to allocate the best ones directly to the most important targets.

- Round quota restriction revises the allocation order in selection based on the decision maker's priorities following the SDP algorithm, but its impact is not clear-cut: the restriction may diversify the group of contenders.

- The SCP algorithm also applies a sort of round quota restriction (unless the number of selections in a round is increased) since the consortium is up for selection only once during the round length based on the number of consortia.

- The final restriction on the number of slots for a consortium is the restriction reported by the consortium itself if it is smaller than the otherwise determining restriction set by the decision maker; the number must not be essentially (e.g. one) larger that the so-called implementation slot restriction.

Both presented solution algorithms, the SCP and SDP, were made to include also the so-called matching allocation possibility, that makes compromises at the cost of the chosen allocation principle, and that should be used (tried) when the direct procedure does not produce a (satisfactory) solution. In matching the consortium does not lose an already gained competitive slot, but it may be replaced by one of a lower priority in order to fill all slots. 
This matching is not chained (i.e. only one consortium may be replaced to free a slot) to comply reasonably with the basic guiding principles. Yet, it is possible that a consortium has to switch from a competitive slot to another a few times, but this would apply to different selections.

The possibility that a solution may have to be sought based on different variable definitions also makes it necessary that the competition programme sticks only to emphasising the goal of following a certain allocation principle.

\section{USE OF PROCEDURE IN DEVELOPMENT CASE}

\subsection{Description of development area}

The developed approach was tested in the development of Vuores, a new municipal district of the City of Tampere, Finland. Vuores will be home to nearly 14000 people with workplaces and comprehensive services (City of Tampere, 2007). Mäyränmäki is the first section of Vuores to be built. In the component master plan it is designated primarily as an area of compact low-rise housing.

Mäyränmäki comprises a workplace- and service-weighted central block, adjoining residential blocks and a one-family housing area to the north. The total number of inhabitants is estimated to be around 800 and the residential floor area 35000 sqm. Each residential block borders on a recreation area.

The pilot project for planning in partnership originally covered five residential blocks (nos. 7601-7605; total building rights for 24000 floor sqm) and one so-called central block reserved primarily for business premises (no. 7600; 12000 floor sqm). The one-family house areas were excluded from the competition. The city reserved the right to divide each individual block between the competi- tors as well as to reject proposals partly or in total.

Guidelines for the competition were provided in the competition programme (City of Tampere, 2005a) and its 15 appended documents that included base maps, a draft for a detailed plan, aerial photographs and numerous documents describing general goals and plans and surveys concerning the area.

\subsection{Allocation phase procedures}

Entry into the competition was open for developers, construction companies and other organisations that considered themselves capable of implementing blocks. The entrants had to submit material proving their competence as implementers and for establishing their ranking order.

Moreover, the consortia were expected to list their blocks of choice in order that teams found competent and ranked high could be selected for targets that they were especially motivated to implement. In practice, the consortia had to answer the questions of Table 3. The basic principle was that a consortium that did not indicate sufficient interest for a block would not be selected to implement it.

A total of 14 consortia registered for the competition, all of which were found competent (cf. Table 1, part A), and were included in the competitor allocation process. The qualifications of consortia were assessed by identifying the differences in properties (cf. Table 1, part B) and the total points were calculated by the method of weighted points. Then, the consortia were placed in ranking order based on total points.

The interest of the consortia focused on the residential blocks. Only one was interested in the business block which was therefore excluded from the competition. Thus, allocation involved five residential blocks. Of the alternative allocation strategies, the SCP method was selected for use with the variables of Table 4 : 
Table 3. Basic allocation data requested from consortia

1. Assign priority numbers $(1,2,3, \ldots)$ to those blocks in the draft for a detailed plan (7600 to 7605$)$ to whose design and implementation your consortium is willing to commit itself (based on the terms of items 2 and 3), should it be selected:

7600:_ 7601:_ 7602:__ 7603:__ 7604:__ 7605:

2. What is the maximum number of competitions related to design of blocks your team is willing to participate in? (Competition slot restriction)

3. If your team wins a competition for more than one block, how many blocks is it willing to implement/ build?

(Implementation slot restriction)

Table 4. Allocation variable selections

\begin{tabular}{lll}
\hline Variable & Symbol & Value \\
\hline Consortia for round 1 & $\mathrm{n}_{\mathrm{t}}(1)$ & 14 \\
Consortia for rounds 2 to $\infty$ & $\mathrm{n}_{\mathrm{t}}(2)$ to $\mathrm{n}_{\mathrm{t}}(\infty)$ & 14 \\
Selections at a time & $\mathrm{c}_{\mathrm{r}}(1)$ to $\mathrm{c}_{\mathrm{r}}(\infty)$ & 1 \\
Max. slots for consortium & $\mathrm{c}_{\mathrm{d}}$ & 2 \\
Slots per block & $\mathrm{w}$ & 3 \\
Matching allocation & - & Not used \\
\hline
\end{tabular}

all consortia were allowed tos choose one competition slot in turn - the number of slots per block was generally three.

A Microsoft ${ }^{\circledR}$ Excel application, for which the algorithms were programmed as Visual Basic macros, was used for counting points and allocation. More detailed presentation of the application is dispensed with here, but the format of Table 5 corresponds to its final output. There the consortia are in ranking order, but their actual names are replaced by letters because only the selections were publicised and feedback to the consortia as concerned their competitors was anonymous. In other respects, the table corresponds to the actual situation. For instance, the shown priorities of the consortia correspond to the priorities reported by each consortium in ranking order.

Table 5 also reveals the slots won by consortia by showing the related selection rounds in parentheses in connection with each realised priority. The selected consortia are also shown in summarised form at the top of the table.

The application was made to output the events of the allocation process also to log the key elements of this relatively simple $d i$ rect allocation case are shown in Table 6 . The aim of logging was to help verify the logical flow of allocation and proper functioning of the application in the several test runs prior to use which naturally also covered testing of the more challenging matching allocation. Possible slight incongruity of the graphic presentation and the programming, however, leaves room for some reservation.

Three consortia were selected for each block-specific competition on the basis of the allocation result. Moreover, the city wanted to include consortium $\mathrm{J}$, only interested in the competition for block 7602, which was excluded in the allocation. The two consortia ranked the best were allowed to compete in two parallel competitions while the rest could only participate in one. 
Table 5. Results of allocation

\begin{tabular}{|c|c|c|c|c|c|c|c|c|c|}
\hline & Block [\#] & & 7601 & 7602 & 7603 & 7604 & 7605 & & \\
\hline & Size [Floor sqm] & & 5000 & 5000 & 7500 & 3500 & 3000 & & \\
\hline & Consortia & & $\mathrm{C}$ & $\mathrm{D}$ & $\mathrm{A}$ & $\mathrm{E}$ & $\mathrm{M}$ & & \\
\hline & selected for & & I & $\mathrm{F}$ & $\mathrm{B}$ & $\mathrm{L}$ & $\mathrm{N}$ & & \\
\hline & competition & & $\mathrm{K}$ & $\mathrm{G}$ & $\mathrm{H}$ & $\mathrm{B}$ & $\mathrm{A}$ & & \\
\hline (t) & Consortium & Grade & \multicolumn{5}{|c|}{ Priority / (round selected) } & $\mathrm{CSR}^{(*)}$ & $\operatorname{ISR}^{(* *)}$ \\
\hline 1 & $\mathrm{~A}$ & 88 & 3 & 2 & $1 /(1)$ & 5 & $4 /(2)$ & 3 & 2 \\
\hline 2 & $\mathrm{~B}$ & 86 & 2 & 4 & $1 /(1)$ & $3 /(2)$ & - & 2 & 2 \\
\hline 3 & $\mathrm{C}$ & 83 & $1 /(1)$ & - & - & - & - & 1 & 1 \\
\hline 4 & $\mathrm{D}$ & 77 & - & $1 /(1)$ & - & - & - & 1 & 1 \\
\hline 5 & $\mathrm{E}$ & 66 & 3 & 2 & - & $1 /(1)$ & - & 1 & 1 \\
\hline 6 & $\mathrm{~F}$ & 59 & - & $1 /(1)$ & - & - & 2 & 2 & 2 \\
\hline 7 & $\mathrm{G}$ & 59 & 2 & $1 /(1)$ & 3 & 4 & 5 & 2 & 2 \\
\hline 8 & $\mathrm{H}$ & 57 & 2 & 3 & $1 /(1)$ & - & - & 3 & 3 \\
\hline 9 & I & 57 & $2 /(1)$ & 1 & 3 & - & - & 2 & 2 \\
\hline 10 & $\mathrm{~J}$ & 52 & - & 1 & - & - & - & 1 & 1 \\
\hline 11 & $\mathrm{~K}$ & 46 & $2 /(1)$ & - & 1 & - & - & 1 & 1 \\
\hline 12 & $\mathrm{~L}$ & 41 & 4 & 5 & 3 & $1 /(1)$ & 2 & 2 & 2 \\
\hline 13 & $\mathrm{M}$ & 30 & 3 & 2 & 1 & 5 & $4 /(1)$ & 3 & 3 \\
\hline 14 & $\mathrm{~N}$ & 23 & - & - & - & 2 & $1 /(1)$ & 2 & 1 \\
\hline
\end{tabular}

* Competition slot restriction (CSR) describes the maximum number of blocks the consortium is willing to compete for.

** Implementation slot restriction (ISR) describes the maximum number of blocks the consortium is willing to implement.

\subsection{Follow-up design phase procedures}

All 14 consortia selected for the competitions prepared and submitted a design proposal while the two best teams submitted proposals for two targets in accordance with the specified competition slot allocation. An evaluation group assessed the proposals (based on criteria of Table 1, part C) without knowing who had prepared them: the envelopes containing the names of the consortia were opened only after the city board had confirmed the results of the assessment and the respective proposal for a resolution (City of Tampere, 2005b). It included separate decisions on the actual competitions and actual selection proposals after assessment of compatibility of adjacent block solutions.
In the case of three blocks, the consortium that submitted the best design was selected as the planning partner. An additional block quite near the area subject to competition was also assigned to one of the consortia that placed second in these competitions.

In the case of the fourth block, the proposal that was considered excellent and placed second was eventually selected since it was deemed to be more compatible with the site and the solutions for the adjoining blocks in general than the proposal that scored the highest points. Here, the consortium judged best by a close margin was assigned another block in the immediate vicinity of the competed blocks.

In the fifth competition, none of the design proposals was found implementable due to 
Table 6. Logging of the allocation procedure

\begin{tabular}{|c|c|c|c|}
\hline Round & Consortium & Priority & Event explanation \\
\hline 1 & $\mathrm{~A}$ & 1 & was entered in competition for block 7603 \\
\hline 1 & $\mathrm{~B}$ & 1 & was entered in competition for block 7603 \\
\hline 1 & $\mathrm{C}$ & 1 & was entered in competition for block 7601 \\
\hline 1 & $\mathrm{D}$ & 1 & was entered in competition for block 7602 \\
\hline 1 & $\mathrm{E}$ & 1 & was entered in competition for block 7604 \\
\hline 1 & $\mathrm{~F}$ & 1 & was entered in competition for block 7602 \\
\hline 1 & $\mathrm{G}$ & 1 & was entered in competition for block 7602 \\
\hline 1 & $\mathrm{H}$ & 1 & was entered in competition for block 7603 \\
\hline 1 & $\mathrm{I}$ & 1 & could not be entered in competition for block 7602 , no room \\
\hline 1 & I & 2 & was entered in competition for block 7601 \\
\hline 1 & $\mathrm{~J}$ & 1 & could not be entered in competition for block 7602 , no room \\
\hline 1 & $\mathrm{~J}$ & & could not be entered for any competition \\
\hline 1 & $\mathrm{~K}$ & 1 & could not be entered in competition for block 7603 , no room \\
\hline 1 & $\mathrm{~K}$ & 2 & was entered in competition for block 7601 \\
\hline 1 & $\mathrm{~L}$ & 1 & was entered in competition for block 7604 \\
\hline 1 & $\mathrm{M}$ & 1 & could not be entered in competition for block 7603 , no room \\
\hline 1 & M & 2 & could not be entered in competition for block 7602 , no room \\
\hline 1 & M & 3 & could not be entered in competition for block 7601 , no room \\
\hline 1 & $\mathrm{M}$ & 4 & was entered in competition for block 7605 \\
\hline 1 & $\mathrm{~N}$ & 1 & was entered in competition for block 7605 \\
\hline 2 & $\mathrm{~A}$ & 2 & could not be entered in competition for block 7602 , no room \\
\hline 2 & $\mathrm{~A}$ & 3 & could not be entered in competition for block 7601 , no room \\
\hline 2 & $\mathrm{~A}$ & 4 & was entered in competition for block 7605 \\
\hline 2 & $\mathrm{~B}$ & 2 & could not be entered in competition for block 7601 , no room \\
\hline 2 & $\mathrm{~B}$ & 3 & was entered in competition for block 7604 \\
\hline 2 & $\mathrm{C}$ & & overall quota for team was filled \\
\hline 2 & $\mathrm{D}$ & & overall quota for team was filled \\
\hline 2 & $\mathrm{E}$ & & overall quota for team was filled \\
\hline 2 & $\mathrm{~F}$ & 2 & could not be entered in competition for block 7605 , no room \\
\hline 2 & $\mathrm{~F}$ & & could not be entered for any competition \\
\hline$\ldots$ & $\ldots$ & $\ldots$ & $\ldots$ \\
\hline 3 & $\mathrm{~N}$ & 2 & could not be entered in competition for block 7604 , no room \\
\hline 3 & $\mathrm{~N}$ & & could not be entered for any competition \\
\hline 3 & & & no allocations in the round $=>$ termination \\
\hline
\end{tabular}

the special challenges presented by the target. Therefore, the block was sent back to preparatory planning where the designated use of the area was finally changed.

The design competition produced good plans that were noted to have improved significantly later during the follow-up design cooperation. Then, the designs for various blocks were matched to attain the best possible end results also on the areal level. At the writing of this, the plan proposal is ready, but stuck in the legal process which has prevented the (quick) launching of the construction work. 


\section{DISCUSSION AND CONCLUSIONS}

\subsection{Workability of the procedure}

At various phases of implementation inquiries were directed at representatives of the consortia and the city/planner participating in the competition and the cooperation process. Generally, it can be said that the change in the operating paradigm was considered a success (Nykänen et al., 2007; Lahdenperä, 2008) and promising as concerns further development possibilities. It was reported that the end result of the process was a diverse local plan of high quality which could not have been achieved without the competitive cooperation procedure.

However, the questions were so general that they do not provide a picture of the workability of the algorithms themselves. They were best at describing the practicality of the preselection/allocation phase and the clarity and content of the competition criteria. None of the respondents found them worse than neutral (but some found them better). Likewise, the 3-4 competitors selected to compete for each block was considered a practical number.

Empirical evaluation of the allocation procedure is based on the fact that the city adhered to the above-presented result produced by the algorithm in selecting the competitors. It is natural that the selection panel did not delve deeply into the details of algorithms and the allocation process but arrived at decisions on the basis of the presentation of principles and Table 5.

A great concern in decision making was to include at least one consortium that did well in the evaluation in each of the competitions. Alternative solutions were sought based on a few different control variable values which justified the systematic approach and its automation.

The pilot project indicates that the allocation procedure solves the practical problem and also works in real life. Also, despite the complicated structure of the algorithms, their basic principles are simple and easy to use as a computer application. Moreover, the results seem to possess theoretical novelty value since corresponding solutions could not be found.

In theoretical terms, the similarity of the solution principles with the earlier mentioned competition theoretical views and cooperation benefits is apparent. Besides, the solution applies the ideas of the expectancy theory recapitulated by Bresnen and Marshall (2000) and Halepota (2005), for instance, to development competitions. The concepts of confidence in one's own competence (promoted by the fair and transparent process), consideration of building rights as a reward (especially for prioritized targets), and sufficient likelihood of success (due to short-listing and allocation) are incorporated into the created multi-phased parallel competition model to generate the preconditions required by the other theories to function properly in areal real estate development.

Thus, the four key criteria specific to the constructive research approach can be considered to have been met (cf. Kasanen et al., 1991) although the final verdict on the workability and significance of the constructions can only be rendered after longer experience from their use.

So far it has been possible to apply only one of the algorithms in an actual development project since the SCP model was selected for use in the pilot project. The other one did, however, pass test runs with fictitious competition cases proving that it conforms to the objectives set in Section 3.3 (as defined in Sec. 3.4). The SDP algorithm also passes the so-called weak market test (introduced by Kasanen et al., 1991) meaning that decision makers have indicated their readiness to put the procedure to use when a similar decision making situation comes up in future competitions. The great majority of the principles and solution procedures are common to both pre- 
sented algorithms indicating that the conducted testing also partly supports the practicality of the other procedure which makes it worth presenting as a conceptual development and part of the overall solution.

\subsection{Future development possibilities}

There are several variables that guide selection, and they are to be selected case-bycase based on the aims of projects and application situations. The result of allocation is often sensitive to the slightest changes in boundary conditions and priorities, and there is no single correct way to allocate. All depends on the valuations and choices of decision makers. On the other hand, we are also faced with a decision making situation where a solution may not always be found.

Setting of boundary conditions may also be experimental which involves comparison of the logicalness and reasonableness of the results achieved by various means. In that, IT is of key importance. An allocation application (which naturally also covers the preceding evaluation and comparison phase) might even solve the presented algorithms automatically based on different variable values, compare the solutions by criteria (parameters) to be developed, and suggest the best solution without separate runs by the decision maker.

Such parameters could apply to the ranking order of selected actors, its competition-specific distribution, and the evenness of the distribution between competitions. The priorities leading to selection in relation to the ranking order of the consortia would also be of key importance. Use of such criteria would also correspond to chaining replacement of consortia to free competition slots in matching allocation contrary to the present practice.

On the other hand, when using parameterbased evaluation, consortia could be allocated to different competitions, even randomly, by going through all relevant selection alterna- tives. The procedure would have the advantage of being able to discover good compromise solutions in situations where the presented algorithms do not work. For instance, the transfer of the best consortium from the block of its first choice to the one of its second choice may be a small concession if the transfer, including multiplier effects, allows an otherwise favourable solution in a situation where the slots cannot otherwise be filled. However, that involves basically a different allocation strategy and is as such excluded from this paper.

The presented algorithms, by contrast, are built on the priority principles and comply with them especially as concerns the top consortia. The idea is that compromises are made outside this group. An advantage of the approach based on a systematic algorithm is that, if necessary, it may occasionally be used also without a computer application. This is important since it can be assumed that projects like this are not likely to constitute the mainstream of areal real estate development in the foreseeable future.

\subsection{Conclusions}

The presented development work was based on the idea that changeover from separate and consecutive planning and construction design to a process based on parallel cooperative planning makes for more effective operations. The work developed partner selection that uses detailed allocation algorithms to support the cooperative approach.

Selection was based on competitiveness which allows finding the most potential actors and best ideas for areal development. Production of quality requires that consortia are selected in ranking order. When decision making is based on expertise, objectivity and transparency, the operational model is believable and qualitative goals genuinely guide the activities of candidates. This, again, helps launch a positive cycle of development throughout the 
construction sector. Emphasis on quality factors is especially important in the selection of planning partners as long as the factors guiding construction have not yet formed.

The developed approach was tested in a pilot project, and the results support the workability and usefulness of the presented solution. Consequently, it is recommended that the results be adopted more widely. It is also true that the targets are diverse, and that the procedure is not suited for guiding all areal development projects. For instance, in targets where design ideas are easily applicable to different blocks, the competition for partnership can be conducted without the presented blockspecific allocation.

\section{REFERENCES}

Alexander, E. and Witzling, L. (1990) Planning and urban design competitions: introduction and overview, Journal of Architectural and Planning Research, 7(2), pp. 91-104.

ATL et al. (2006) Rakennusalan suunnittelukilpailun periaatteet [Principles for design competitions in real estate and construction]. ATL, ASRA, RIA, RT, SAFA, SKY, MARK, RIL, Rakli, SKOL \& Ornamo, Helsinki. (In Finnish)

Bresnen, M. and Marshall, N. (2000) Motivation, commitment and the use of incentives in partnership and alliances, Construction Management and Economics, 18(5), pp. 587-598.

City of Tampere (2005a) Vuoreksen Mäyränmäen korttelikilpailu. Kilpailuohjelma [Competition for Mäyränmäki blocks of Vuores. Competition programme]. (In Finnish)

City of Tampere (2005b) Vuoreksen Mäyränmäen korttelikilpailu. Palkintolautakunnan arvostelupöytäkirja [Competition for Mäyränmäki blocks of Vuores. Assessment report of the jury]. (In Finnish)

City of Tampere (2007) Vuores - Uutta ihmisläheistä ja ihmisen kokoista asumista nykyajan kaupunkilaiselle [Vuores - New pleasant living environment of human scale for today's urban dwellers]. [Online] Available at: <http://www. tampere.fi/vuores> (In Finnish)

Clemen, R. (1996) Making hard decisions. An introduction to decision analysis. $2^{\text {nd }}$ ed. Pacific Grove, Duxbury Press.
Eerolainen, J. (2005) Maankäyttösopimukset - aitoa kumppanuutta? [Land use agreements pure partnership?] Maankäyttö, (4), pp. 12-14. (In Finnish)

Eley, J. (1990) Urban design competitions: a British perspective, Journal of Architectural and Planning Research, 7(2), pp. 132-141.

Fisher, P., Robson, S. and Todd, S. (2007) The disposal of public sector sites by "development competition”, Property Management, 25(4), pp. 381-399.

Gramercy Books (1994) Webster's Encyclopedic Unabridged Dictionary of the English Language, New Jersey.

Halepota, H. (2005) Motivational theories and their application in construction, Cost Engineering, 47(3), pp. 14-18.

Huovila, P. (2005) Vuores - elävä ja omaleimainen pikkukaupunki. Ratkaisuehdotuksen arviointikriteerit [Vuores - a lively and unique town. Evaluation criteria of proposed solution]. Unpublished memorandum 23.11.2005. (In Finnish)

Kasanen, E., Lukka, K. and Siitonen, A. (1991). Konstruktiivinen tutkimusote liiketaloustieteessä [Constructive approach in business studies]. The Finnish Journal of Business Economics, 40(3), pp. 301-329. (In Finnish, summary in English)

Kasanen, E., Lukka, K. and Siitonen, A. (1993) The constructive approach in management accounting research, Journal of Management Accounting Research, 5, pp. 241-264.

Kauppinen, H. (2001) Tontinluovutuskilpailut Helsingissä [Design competitions for plots in Helsinki]. In: Rakennusprojektit [Construction projects] 2001, Hyvinkää 17.-18.5.2001. Helsinki: The Real Estate Education and Training Institute. (In Finnish)

Kreukels, A. and Spit, T. (1990) Public-private partnership in the Netherlands, Tijdschrift voor Economische en Sociale Geografie, 81(5), pp. 388-392.

Kurunmäki, K. (2005) Partnership in Urban Planning. "Development Area" in National and Local Contexts in Finland, Germany and Britain. Tampere University of Technology, Tampere.

Lahdenperä, P. (2001) Design-Build Procedures. Introduction, illustration and comparison of U.S. modes. VTT Publications 452, Technical Research Centre of Finland (VTT), Espoo. 
Lahdenperä, P. (2007) Aluerakennuskohteiden kehityskumppaneiden systemaattinen valinta [Systematic selection of partners for areal development projects]. VTT Research Notes 2380, Technical Research Centre of Finland (VTT), Espoo. (In Finnish)

Lahdenperä, P. (2008) Synchronizing urban and building design: experiences from competitive planning in partnership. Paper presented at the CIB W55/W65 Transformation through Construction Conference, 15-17 November 2008, Dubai, Heriot-Watt University.

Lahdenperä, P. and Sulankivi, K. (2001) Monikriteerinen toteuttajan valinta rakennushankkeessa. Kansainvälinen kartoitus ja menetelmäperusta [Multi-criteria selection of a building project's implementers. International situation and methodological base]. VTT Publications 855, Technical Research Centre of Finland (VTT), Espoo. (In Finnish)

Lahdenperä, P. Nykänen, V. and Rintala, K. (2005) Elinkaarimallit. Tilapalveluhankkeiden vaihtoehtoiset toimintatavat [Design-Build-Operate. Alternative modes of operation for accommodation services]. VTT Research Notes 2315, Technical Research Centre of Finland (VTT), Espoo. (In Finnish)

Laki (2006) Laki tilaajan selvitysvelvollisuudesta ja vastuusta ulkopuolista työvoimaa käytettäessä 1233/2006 [Act on the Contractor's Obligations and Liability when Work is Contracted Out, 1233/2006] (2006) Edita, Helsinki. (In Finnish, unofficial translation in English)

Maankäyttö (1999) Maankäyttö- ja rakennuslaki 132/1999 [Land Use and Building Act 132/1999] (1999). Edita, Helsinki. (In Finnish, unofficial translation in English)

Mäkinen, V. (1980) Yrityksen toiminnan tutkimisen lähestymistavoista. Toiminta-analyyttisen tutkimusstrategian kehittelyä [Approach to research in business management. Sketching a culture-paradigmatic strategy]. University of Tampere. Series A1: Research 17. (In Finnish)

Nykänen, V., Huovila, P., Lahdenperä, P., Lahti, P., Riihimäki, M. and Karlund, J. (2007) Kump- panuuskaavoitus aluerakentamisessa. Beyond Vuores - tutkimus [Collaborative urban planning. Case Beyond Vuores]. VTT Research Notes 2393, Technical Research Centre of Finland (VTT), Espoo. (In Finnish)

Rakentamisen (2007) Rakentamisen Laatu RALA [Construction Quality Association RALA] [Online] Available at: <http://www.rala.fi/> (In Finnish)

RIL (2000) Kilpailusäännöt rakennusinsinööritaitokilpailussa [Competition rules in a civil engineering competition]. Association of Finnish Civil Engineers RIL, Helsinki. (In Finnish)

Rowley, A. (1998) Private-property decision makers and the quality of urban design, Journal of $\mathrm{Ur}$ ban Design, 3(2), pp. 151-173.

Saaty, T. (2001) Decision making for leaders. The analytic hierarchy process for decisions in a complex world. 3rd ed. Vol. II, AHP Series, RWS Publications, Pittsburgh.

SAFA (1994) Kilpailusäännöt Suomessa järjestettäviä kansallisia arkkitehtuurikilpailuja varten [Competition rules for national architectural competitions arranged in Finland]. The Finnish Association of Architects SAFA, Helsinki. (In Finnish)

Stenberg, A.-C. and Kadefors, A. (2000) Procurement practices and innovation processes: A case study of a developer competition for green building. In: Serpell, A. (ed.) Information and Communication in Construction Procurement. CIB W92 Procurement System Symposium, Santiago, Chile, April 24-27. Santiago, CL: Department of Construction Engineering and Management, Pontificia Universidad Católica de Chile. CIB Proceedings, Publication 249, pp. 767-782.

Taylor, N. (1998) Urban Planning Theory Since 1945. Sage, London.

Väyrynen, E. (2007) Planning and implementation - from separation to joint processes. Nordic Planning Research Symposium on Local Authority Planning in Change: Beyond Dichotomies, August 16-18, 2007, Oulu. University of Oulu, Department of Architecture. 


\section{SANTRAUKA}

\section{ETAPINIAI DAUGIATIKSLIAI TERITORIJŲ PLĖTROS KONKURSAI: ALGORITMAI KONKURSŲ DALYVIAMS SKIRSTYTI}

\section{Pertti LAHDENPERÄ}

Plètojant nekilnojamaji turtą naujose teritorijose, vieši ir privatūs asmenys dažniausiai savo pareigas vykdo paeiliui. Tačiau planavimo procesui būtų tik geriau, jei tuo pačiu metu prisidètų ir visuomenè, ir vystytojai, ir projektuotojai. Tam vèlgi reikia, kad savivaldybè paskelbtų konkursą ir pasirinktu privačiu partnerių grupes prieš užbaigdama vietini detaluji planą didžiausią potencialą turintiems dalyviams aptikti ir geriausioms idejoms surinkti, kokybiškai miesto struktūrai išvystyti. Kai teritoriju plètros projektas apima kelis kvartalus, o kuriant konkurencingus sprendimus idedama daug darbo, reikia gerai suplanuoto atrankos proceso. Yra sukurtas novatoriškas daugiatikslis konkurso procesas, pristatomas šiame darbe, daugiau dèmesio skiriama paskirstymo algoritmams, kuriuos naudojant iš daugybès registruotų kandidatu galima atrinkti tinkamiausius tolesniems tuo pat metu vykdomiems konkursams. Toks būdas patikrintas realiame nekilnojamojo turto plètros projekte, kuris vyko Vuores savivaldybès teritorijoje, ir būtent dèl šios priežasties pradètas šis tyrimas. 